\title{
Terrorism vulnerability assessment in Java Island: a spatial multi-criteria analysis approach
}

\author{
Asep Adang Supriyadi' ${ }^{1,2}$, Masita Dwi Mandini Manessa ${ }^{3}$ \\ ${ }^{1}$ Department of Defense Industry, Indonesia Defense University, Sentul, Indonesia \\ ${ }^{2}$ National Counter Terrorism Agency, Sentul, Indonesia \\ ${ }^{3}$ Department of Geography, University of Indonesia, Depok, Indonesia
}

Received: 2019-05-18

Accepted: 2020-05-04

Keywords:

Terrorism;

Vulnerability Index;

Java Island;

Spatial Multi-Criteria Decision

Correspondent email:

aadangsupriyadi@gmail.com

\begin{abstract}
Terrorism is one of the Indonesia's national security threat. The attack mostly happens in Java Island, attracted by the dense population, also because the island is a center for economic and governance. The spatial pattern of terrorism attack shows correlations with the spatial density of the targeted attack. Therefore, this study assesses the spatial vulnerability of Java Island using a spatial multi-criteria analysis (SMCA). The main attributes analyzed were the density of the past terrorist attack, arrested area, police/ military facility, government facility, business center, densely populated area, and church, determine that in the case of a terrorist attack is strongly affected by the attraction of the area.
\end{abstract}

2020 by the authors. Licensee Indonesian Journal of Geography, Indonesia.

Creative Commons

Attribution(CC BY NC) licensehttps://creativecommons.org/licenses/by-nc/4.0/,

\section{Introduction}

Over the past several decades, terrorism has been started to be appeared in Indonesia (GTD, 2017). The terrorist act was increased after the fallen of Soeharto regime in 1998, followed by the rise of Islamic extremist groups which enroots their ideology and value with the movement from the Middle East (Umar, 2010). Terrorism in Indonesia triggered by five factors: the religion factor which is caused by a misinterpretation of its teaching; social-economic factor; the charismatic leaders who are able to spread the doctrine; low educational level of the society; and geographical factor (Mubarak, 2012). Therefore, the geographical expanse of Indonesia benefited the terrorist group as their mobility become difficult to detect. At this point of view, the spatial aspect plays a vital role in the occurrence of terrorism in Indonesia.

Study on terrorism that based on spatial approach have expanded with recent research examining whether using the risk terrain modeling (Onat, 2016; Onat \& Gul, 2018), distance and pattern analysis (Arva \& Piazza, 2016; Griffiths, Johnson, \& Chetty, 2017; LaFree, Dugan, Xie, \& Singh, 2012; Li, Sun, Chen, \& Huang, 2016), and hotspot analysis (Braithwaite \& LI, 2007; Guo, Liu, Yu, \& Li, 2016; Nemeth, Mauslein, \& Stapley, 2014; Python, Illian, Jones-Todd, \& Blangiardo, 2016). Many parameters influence the terrorism act. In order to combine, analyze, and handle the full range of settings, the use of spatial analysis such us Spatial MultiCriteria Analysis (SMCA) used entirely to evaluate the terrorism act spatially. SMCD methods have applied in several vulnerability studies (Armaş \& Gavris, 2013; Maanan et al., 2018; Machado, Valle Júnior, Sanches Fernandes, \&
Pacheco, 2018; März, 2018; Saidi et al., 2017) used evaluate phenomena that related geographically. However, an SMCA approach has rarely, if at all, applied to terrorism study.

The primary purpose of this study is to determine, via the SMCA approach, the vulnerability on terrorism. Java Island is chosen as a study site since mostly the terrorist attack in Indonesia happen here (Alius, 2018). The vulnerable model build based on two parameters: present of terrorism act and targeted facility. Assume that terrorist likely to repeat the act in the same location or close, nearby their house, and create large chaotic. The summary of the selective facility in Java Island shown in Table 1 (GTD, 2017; National Counter Terrorisme Agency (Badan Nasional Penanggulangan Terorisme), 2018). As Military/Police, Private Citizens \& Property, Place for Worship (mainly Church), Business, and Government are the most common targeted facility; then this study used the mentioned facility as an input of targeted facility for building the vulnerability model.

\section{The Methods}

\section{Datasets}

The sources of spatial data used in this study depicted in Table 2. Table columns include references to data type, data period, specific use in the SMCA, and data ownership. In total seven (7) factors/variable (Past attack, capture site, residentials, Military/Police facility, Church, Business, Government), were determined for this study of terrorism vulnerability. The past attack and terrorist capture site dataset were in the form of the tabular dataset with coordinate attribute and address, respectively. Both tabular 
Table 1. Targets by the frequency of attacks in Java Island

\begin{tabular}{lc}
\hline Target & Number of attacks \\
\hline Military/Police & 174 \\
Private Citizens \& Property & 169 \\
Religious Institutions & 113 \\
Business & 94 \\
Government & 74 \\
Diplomatic & 22 \\
other & 91 \\
Total & 737 \\
\hline
\end{tabular}

Table 2. Data used in the construction of the terrorism vulnerability

\begin{tabular}{llccc}
\hline Parameter & Variables & Data Periods & Operationalization & Data Source \\
\hline \multirow{2}{*}{ Present of Terrorism act } & Past attack & $1990-2019$ & Density & GDT \& BNPT \\
& Terrorist capture site & $2016-2019$ & Density & BNPT \\
& Residential area & 2019 & Density & Indonesia Geospa- \\
& tial Agencies \\
\multirow{5}{*}{ Targeted Facility } & The military/Police facility & 2019 & Density & Google Place API \\
& Church & 2019 & Density & Google Place API \\
& Business (shopping mall) & 2019 & Density & Google Place API \\
& Government & 2019 & Density & Google Place API \\
\hline
\end{tabular}

datasets then converted in to point vector shapefile format using geocode function. While the residential dataset as polygon vector shapefile format was converted in to point vector shapefile format for every $0,005 \mathrm{~km}^{2}$. Last, the Google Place API already under a spatial dataset format. The spatial dataset has projected in the Geographic coordinate system, and datum of WGS-84.

\section{Spatial multi-criteria analysis}

One of the ways in producing and combining spatial data describing the causing factors of phenomena is using SMCA. Siqueira et al. defines five steps in the application of SMCA (Siqueira, Pissarra, do Valle Junior, Fernandes, \& Pacheco, 2017), describe as follows:

First and the second steps are data acquisition from multiple sources (section 2.1) and the normalization. In this study a kernel density analysis was applied for each of the variable's layers, $1 \times 1 \mathrm{~km}$ cells within each density. Then each pixel density value is normalize as an index (0-1) shown in Figure 1 using the following formula:

$$
X_{\mathrm{i}}^{\prime}=\frac{X_{\mathrm{i}}-X_{\min }}{X_{\max }-X_{\min }}
$$

As ${ }^{X_{\mathrm{i}}^{\prime}}$ is normalize density value for pixel i, ${ }^{X_{\mathrm{i}}}$ is density value in pixel $\mathrm{i}$, and $X_{\min }, X_{\max }$, is minimum and maximum density value in dataset.
Third, define the weighting to represent the level of importance between each variable. The analytic hierarchy process (AHP) was used to define the weight of each variable (Saaty, 1989). Moreover, the relative importance of the criteria is asses and then create a consensual judgement (März, 2018). AHP has implement for SMCA and shows a promising result (März, 2018; Ottomano Palmisano, Govindan, Loisi, Dal Sasso, \& Roma, 2016). In this study, three experts from Indonesia National Counter Terrorism Agencies is asked about their perception on the influence of each observed variable to create the vulnerability of an area to terrorist action. The experts assessed the criteria on a linear scale based on Saaty (1989), which value from 1 (less importance) to 9 (most important). Then the result is analyzed in pairwise matrix method.

Four, sensitivity analysis applied to test how sensitive the parameter weight on the vulnerability model using consistency index (CI) (Saaty, 1989). If CR value shows less than $10 \%$ then the matrix is in acceptable level of consistency (Ghorbanzadeh, Feizizadeh, \& Blaschke, 2018).

Five, aggregation step to combine the data to reach the general map of vulnerability (Machado et al., 2018). The terrorism vulnerability map is a result of overlaying of the seven parameters, using the following formula:

Terrorism Vulnerability Index $=\frac{\sum\left(D_{n} \times w_{n}\right)-\sum\left(D_{n} \times w_{n}\right)_{\min }}{\sum\left(D_{n} \times w_{n}\right)_{\max }-\sum\left(D_{n} \times w_{n}\right)_{\min }}$ 
as $\mathrm{D}$ is Normalize density index of variable $\mathrm{n}, \mathrm{w}$ is weight of variable $n$, and $n$ are the seven variable, namely Past attack, capture site, residentials, Military/Police facility, Church, Business, Government. Then the vulnerability index is classified into five class using the equal interval equation.

\section{Result and Discussion}

Analytic Hierarchy Process

Table 2 shows the result of AHP process matrix that based on 3 experts in terrorism studies. The weight is set to $0.04,0.03,0.10,0.21,0.24,0.18$, and 0.21 for past attach, terrorism capture site, residential area, military/police facility, church, business, and government respectively. The 'church' criterion had the highest weighting (0.24), indicate that church is still assumed to be high possibility or influence to the terrorism attract vulnerability. This indicate the number of threats of bombing the church that still happen year by year especially in Christmas and new year eve. The 'residential' criterion had the lowest weighting (0.1) in term of targeted facility aspect, indicate that the a dense populate area has low possibility or influence to the vulnerability of an area. The bomb explosion in the residential area a most incidentally happen due to human failure in assembling bomb process or as suicide bomb due to policy ambush. Moreover, the past attack and terrorism capture site shows the lowest weight. This assumes that based on expert knowledge there is no relation between what happen in the past with the future terrorism action. The random and unpredicted attack are commonly appeared in Indonesia. The repeated location of terrorism action only appears once in Bali, known as "Bali Bomb 1" and "Bali Bomb 2". While in Java Island the number of repeated locations is relatively small.

The sensitivity of APH result is evaluate using the CR value shown in Table 3. As Saaty (1989) explain that the performance of AHP process can be analyze based on CR value. Moreover, the $\mathrm{CR}$ calculated the reliability of the obtained weights from AHP (Banica, Rosu, Muntele, \& Grozavu, 2017). This study CR value show a relative low value at $3.9 \%$ far lower than the maximum $10 \%$ threshold value. Indicate that the weight create from AHP process is reliable.
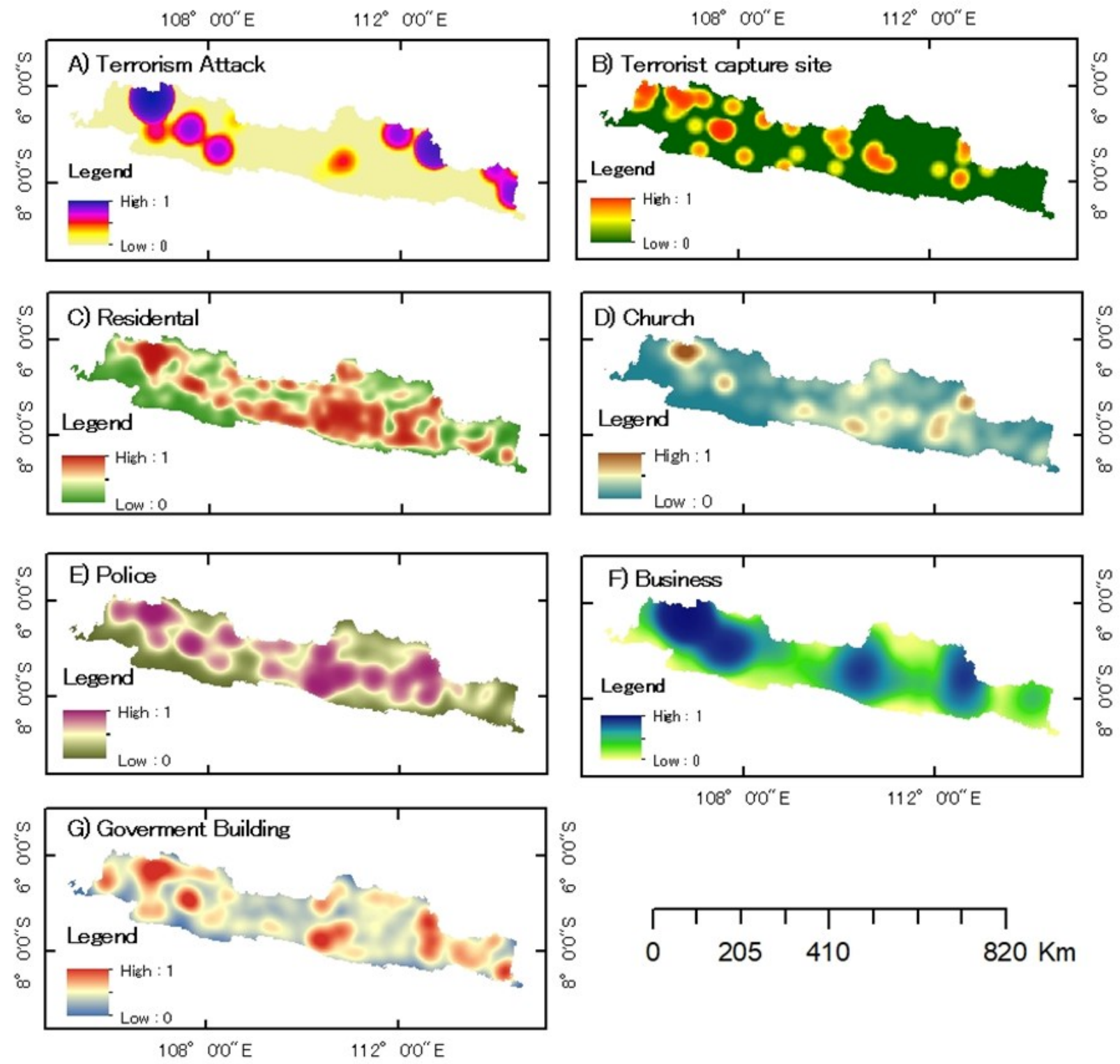

Figure 1. A-G is density (as an index) of variables used in this study 
Table 2 AHP Matrix

\begin{tabular}{|c|c|c|c|c|c|c|c|c|c|c|}
\hline Matrix & & $\begin{array}{l}\text { Past } \\
\text { attach }\end{array}$ & $\begin{array}{c}\text { Ter- } \\
\text { rorism } \\
\text { cap- } \\
\text { ture } \\
\text { site }\end{array}$ & $\begin{array}{l}\text { Resi- } \\
\text { dential } \\
\text { area }\end{array}$ & $\begin{array}{l}\text { Military/ } \\
\text { Police } \\
\text { facility }\end{array}$ & $\begin{array}{c}\text { Churc } \\
\mathrm{h}\end{array}$ & $\begin{array}{l}\text { Busi- } \\
\text { ness }\end{array}$ & $\begin{array}{l}\text { Gov- } \\
\text { ernme } \\
\text { nt }\end{array}$ & $\begin{array}{c}\text { normalized } \\
\text { principal } \\
\text { Eigenvector }\end{array}$ & Rank \\
\hline & & 1 & 2 & 3 & 4 & 5 & 6 & 7 & & \\
\hline Past attack & 1 & 1 & 2 & $1 / 3$ & $1 / 5$ & $1 / 7$ & $1 / 5$ & $1 / 5$ & $4.04 \%$ & 7 \\
\hline $\begin{array}{c}\text { Terrorism } \\
\text { capture site }\end{array}$ & 2 & $1 / 2$ & 1 & $1 / 5$ & $1 / 6$ & $1 / 6$ & $1 / 5$ & $1 / 6$ & $2.93 \%$ & 6 \\
\hline $\begin{array}{r}\text { Residential } \\
\text { area }\end{array}$ & 3 & $23 / 4$ & $45 / 7$ & 1 & $1 / 4$ & $2 / 3$ & $4 / 5$ & $2 / 7$ & $10.25 \%$ & 5 \\
\hline $\begin{array}{r}\text { Military/Police } \\
\text { facility }\end{array}$ & 4 & $45 / 7$ & $61 / 4$ & $42 / 9$ & 1 & $2 / 3$ & $11 / 8$ & $2 / 3$ & $20.77 \%$ & 3 \\
\hline Church & 5 & $64 / 5$ & 6 & $14 / 7$ & $14 / 9$ & 1 & $12 / 9$ & $15 / 7$ & $23.53 \%$ & 1 \\
\hline Business & 6 & $45 / 7$ & $45 / 7$ & $11 / 4$ & $8 / 9$ & $5 / 6$ & 1 & $12 / 7$ & $17.54 \%$ & 4 \\
\hline Government & 7 & $51 / 8$ & 6 & $35 / 9$ & $14 / 9$ & $3 / 5$ & $7 / 9$ & 1 & $20.96 \%$ & 2 \\
\hline
\end{tabular}

Table 3. Sensitivity analysis of AHP

\section{AHP Analytic Hierarchy Process (EVM multiple inputs)}

K. D. Goepel Version 15.09.2018 Free web based AHP software on

Only input data in the light green fields and worksheets!

\begin{tabular}{|c|c|c|c|c|c|c|}
\hline$n=$ & 7 & Number of criteria (2 to 10 ) & Scale: & 1 & & AHP 1-9 \\
\hline $\mathbf{N}=$ & 5 & Number of Participants (1 to 20 ) & $\alpha:$ & 0.1 & Consensus: & $74.3 \%$ \\
\hline$p=$ & 0 & selected Participant ( $0=$ consol. $)$ & 2 & 7 & Consolidated & \\
\hline
\end{tabular}

Objective Terrorism vulnerability

\begin{tabular}{|c|c|c|c|c|c|c|c|c|}
\hline \multicolumn{2}{|c|}{ Author Manessa } & \multirow[b]{2}{*}{ Thresh: } & \multirow[b]{2}{*}{$1 E-08$} & \multirow[b]{2}{*}{ Iterations: } & \multirow[b]{2}{*}{4} & \multirow[b]{2}{*}{ EVM check: } & \multirow[b]{2}{*}{$9.6 \mathrm{E}-09$} & \multirow[b]{3}{*}{$+/-$} \\
\hline Date & 10-Mar-20 & & & & & & & \\
\hline \multirow[t]{11}{*}{ Table } & Criterion & \multicolumn{4}{|l|}{ Comment } & Comment & Weights & \\
\hline & \multirow{7}{*}{$\begin{array}{l}1 \text { Past attack } \\
2 \text { Terrorism capture } \\
3 \text { Residential area } \\
4 \text { The military/Police } \\
5 \text { Church } \\
6 \text { Business } \\
7 \text { Government }\end{array}$} & & & & & & $13.3 \%$ & $2.1 \%$ \\
\hline & & & & & & & $13.5 \%$ & $2.9 \%$ \\
\hline & & & & & & & $9.6 \%$ & $1.6 \%$ \\
\hline & & & & & & & $13.6 \%$ & $1.8 \%$ \\
\hline & & & & & & & $21.3 \%$ & $3.8 \%$ \\
\hline & & & & & & & $16.7 \%$ & $2.8 \%$ \\
\hline & & & & & & & $11.9 \%$ & $1.8 \%$ \\
\hline & 8 & & & & & & $0.0 \%$ & $0.0 \%$ \\
\hline & 9 & \multirow{2}{*}{\multicolumn{4}{|c|}{$\begin{array}{l}\text { for } 9 \& 10 \text { unprotect the input sheets and expand the } \\
\text { question section ("+" in row 66) }\end{array}$}} & & $0.0 \%$ & $0.0 \%$ \\
\hline & 10 & & & & & & $0.0 \%$ & $0.0 \%$ \\
\hline
\end{tabular}

\begin{tabular}{l|lll|l|l|l|}
\hline Result & Eigenvalue & & & Lambda: & 7.085 & MRE: \\
Consistency Ratio & 0.37 & GCl: & 0.04 & Psi: $19.0 \%$ & CR: $1.1 \%$ & \\
\hline
\end{tabular}


Vulnerability Map

Figure 2 summarizes the results obtained for vulnerability map in Java Island. As indicate in Figure 2, $10.36-45.67 \%$ and $43.28-69.74 \%$ area in Java Island were found to be invulnerable to weakly vulnerable, respectively. In contrast, $4.48-9.93 \%$ of Java Island in the spectrum of vulnerable. The same with the strongly to extremely vulnerable category that falls around $0.72-2.3 \%$. In total, the terrorism vulnerable area in Java Island range between $15.86-32.95 \%$.

The percentage area statistical result denotes that most of Java Island categorize to be less vulnerable to terrorism activity. However, the vulnerability map (Figure 3 ) shows that classified area as vulnerable to extremely vulnerable (colored in red to yellow) are concentrated in the capital city of Jakarta and other big cities (i.e. Bekasi, Tangerang, Bogor, Bandung, Semarang, Yogyakarta, Surakarta, Malang, and Surabaya. On the other hand, small cities characterized by low vulnerability (colored in green shade).

This result validates the performance of proposed SMCA for terrorism vulnerability. As nowadays, terrorist act aims not only to create a mass murder but also a psychological fear over the community (Alius, 2018). The vulnerable to extremely vulnerable area that located in high density population will create significantly negative effect to the whole nation, even if in a small scale of attack. As the effect of Bali Bombing give a significant impact to the Indonesia GDP that lost from 6 to 4 percent (Acharya, 2006). The pattern on attacking the big cities on each country has become a common sense (Braithwaite \& LI, 2007), as the recorded in the Global Terrorism Databased (GTD, 2017), mostly happen in the middle east countries. However, the terrorism attack had start to distribute and target countries in Europe, South Asia and South East Asia (LaFree et al., 2012).

This study experiment extending the knowledge on the usage of SMCA approach for terrorism vulnerability model, that never tested before. Compared with the past tested spatial model (risk terrain modeling, distance and pattern analysis, and hotspot analysis), the SMCA approach has proven to be practically applicable in combine with the available open database resource. Moreover, the expected vulnerable area in Java Island based on the proposed SMCA model appeared to be well supported by the fact of terrorism

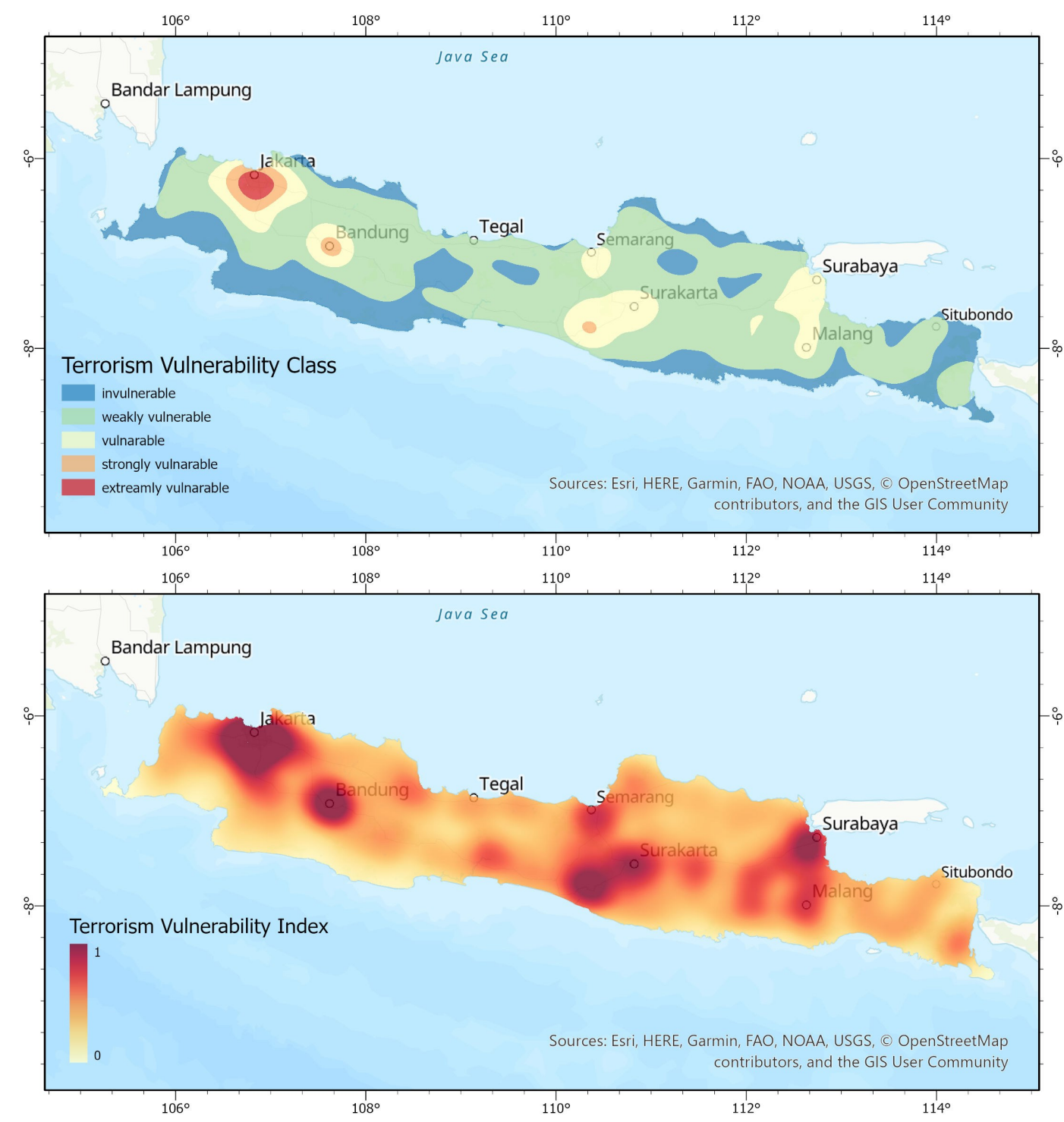

Figure 2. Terrorism Vulnerability map on Java Island: upper) Class; lower) Index 
act over the region (Braithwaite \& LI, 2007; LaFree et al., 2012). Then this method could be applicable to map the entire Indonesia.

Taking together, these results would seem to suggest that the design of counter terrorism program can be focus on the mapped area of vulnerable to extremely vulnerable area create from the proposed model, to prevent the act of terrorist, especially in Indonesia. However, the implementation of SMCA approach for terrorism vulnerability still widely open for improvisation, such defining the vulnerability aspect into physical, social, and economic.

\section{Conclusion}

The spatial vulnerability of terrorism act can give the government a valuable information. This study provides based on the past terrorism act and attractiveness of targeted facility. In case of Java Island, around $10 \%$ of area categorized as vulnerable to terrorism activity. Even shows as a small number, the vulnerable area located in center of governance and business area (Jakarta, Bandung, Surabaya, Solo, Yogyakarta), which even a small chaotic event will give significant effect. In the future research, the SMCA approach will be applied to evaluate the terrorism vulnerability over Indonesia.

\section{Acknowledgment}

The authors would like to thank the Indonesia National Counter Terrorism Agency (BNPT) for the providing the database of Terrorism event. Special thanks to Ari Setiyanto, for revising the English grammar of this article.

\section{References}

Acharya, A. (2006). The Bali Bombings: Impact on Indonesia and Southeast Asia. Center for Eurasian Policy Occasional Research Paper Series II (Islamism in Southeast Asia), 2, 15. Retrieved from https://www.hudson.org/content/ researchattachments/attachment/517/ acharyathebalibombings.pdf

Alius, S. (2018). Threats and Challenges of the Spread of the Radical Terrorism (Ancaman dan Tantangan Penyebaran Paham Radikal Terorisme). Jakarta.

Armaş, I., \& Gavris, A. (2013). Social vulnerability assessment using spatial multi-criteria analysis (SEVI model) and the Social Vulnerability Index (SoVI model) - a case study for Bucharest, Romania. Natural Hazards and Earth System Sciences, 13, 1481-1499. https://doi.org/10.5194/nhess-131481-2013

Arva, B. J., \& Piazza, J. A. (2016). Spatial Distribution of Minority Communities and Terrorism: Domestic Concentration versus Transnational Dispersion. Defence and Peace Economics, 27(1), 1-36. https:// doi.org/10.1080/10242694.2015.1055091

Banica, A., Rosu, L., Muntele, I., \& Grozavu, A. (2017). Towards urban resilience: A multi-criteria analysis of seismic vulnerability in Iasi City (Romania). Sustainability (Switzerland), 9(2). https://doi.org/10.3390/su9020270

Braithwaite, A., \& LI, Q. (2007). Transnational Terrorism Hot Spots: Identification and Impact Evaluation. Conflict Management and Peace Science, 24(4), 281-296. https:// doi.org/10.1080/07388940701643623

Ghorbanzadeh, O., Feizizadeh, B., \& Blaschke, T. (2018). Multicriteria risk evaluation by integrating an analytical network process approach into GIS-based sensitivity and uncertainty analyses. Geomatics, Natural Hazards and Risk, 9(1), 127151. https://doi.org/10.1080/19475705.2017.1413012
Griffiths, G., Johnson, S. D., \& Chetty, K. (2017). UK-based terrorists' antecedent behavior: A spatial and temporal analysis. Applied Geography, 86, 274-282. https:// doi.org/10.1016/J.APGEOG.2017.06.007

GTD. (2017). Global Terrorism Database. University of Maryland.

Guo, W., Liu, H., Yu, A., \& Li, J. (2016). Research on visual analysis methods of terrorism events. International Archives of the Photogrammetry, Remote Sensing and Spatial Information Sciences - ISPRS Archives, 41, 191-196. https:// doi.org/10.5194/isprsarchives-XLI-B2-191-2016

LaFree, G., Dugan, L., Xie, M., \& Singh, P. (2012). Spatial and Temporal Patterns of Terrorist Attacks by ETA 1970 to 2007. Journal of Quantitative Criminology, 28(1), 7-29. https://doi.org/10.1007/s10940-011-9133-y

Li, Z., Sun, D., Chen, H., \& Huang, S. Y. (2016). Identifying the socio-spatial dynamics of terrorist attacks in the Middle East. IEEE International Conference on Intelligence and Security Informatics: Cybersecurity and Big Data, ISI 2016, 175-180. https://doi.org/10.1109/ISI.2016.7745463

Maanan, M. M., Maanan, M. M., Rueff, H., Adouk, N., Zourarah, B., \& Rhinane, H. (2018). Assess the human and environmental vulnerability for coastal hazard by using a multi-criteria decision analysis. Human and Ecological Risk Assessment: An International Journal, 24(6), 1642-1658. https://doi.org/10.1080/10807039.2017.1421452

Machado, E. R., Valle Júnior, R. F. do, Sanches Fernandes, L. F., \& Pacheco, F. A. L. (2018). The vulnerability of the environment to spills of dangerous substances on highways: A diagnosis based on multi criteria modeling. Transportation Research Part D: Transport and Environment, 62, 748-759. https://doi.org/10.1016/ J.TRD.2017.10.012

März, S. (2018). Assessing the fuel poverty vulnerability of urban neighbourhoods using a spatial multi-criteria decision analysis for the German city of Oberhausen. Renewable and Sustainable Energy Reviews, 82(2), 1701-1711. https:// doi.org/10.1016/j.rser.2017.07.006

Mubarak, Z. (2012). Fenomena Terorisme di Indonesia区: Kajian Aspek Teologi, Ideologi dan Gerakan. Jurnal Studi Masyarakat Islam, 15(2), 240-254. https:// doi.org/10.11650/tjm.17.2013.3794

National Counter Terrorisme Agency (Badan Nasional Penanggulangan Terorisme). (2018). Indonesia Terrorism Database. National Counter Terrorisme Agency (Badan Nasional Penanggulangan Terorisme).

Nemeth, S. C., Mauslein, J. A., \& Stapley, C. (2014). The primacy of the local: Identifying terrorist hot spots using geographic information systems. Journal of Politics, 76(2), 304-317. https://doi.org/10.1017/S0022381613001333

Onat, I. (2016). An analysis of spatial correlates of terrorism using risk terrain modeling. Terrorism and Political Violence, 122. https://doi.org/10.1080/09546553.2016.1215309

Onat, I., \& Gul, Z. (2018). Terrorism Risk Forecasting by Ideology. European Journal on Criminal Policy and Research, 24(4), 433-449. https://doi.org/10.1007/s10610-017-9368-8

Ottomano Palmisano, G., Govindan, K., Loisi, R. V., Dal Sasso, P., \& Roma, R. (2016). Greenways for rural sustainable development: An integration between geographic information systems and group analytic hierarchy process. Land Use Policy, 50, 429-440. https://doi.org/10.1016/ j.landusepol.2015.10.016

Python, A., Illian, J., Jones-Todd, C., \& Blangiardo, M. (2016). A Bayesian Approach to Modelling Fine-Scale Spatial Dynamics of of Non-State Terrorism: World Study, 20022013. ArXiv. https://doi.org/10.1111/rssa.12384

Saaty, T. L. (1989). Group Decision Making and the AHP. In The Analytic Hierarchy Process (pp. 59-67). https:// doi.org/10.1007/978-3-642-50244-6_4

Saidi, S., Hosni, S., Mannai, H., Jelassi, F., Bouri, S., \& Anselme, B. (2017). GIS-based multi-criteria analysis and vulnerability 
method for the potential groundwater recharge delineation, case study of Manouba phreatic aquifer, NE Tunisia. Environmental Earth Sciences, 76(15), 511. https:// doi.org/10.1016/j.powtec.2015.10.016

Siqueira, H. E., Pissarra, T. C. T., do Valle Junior, R. F., Fernandes, L. F. S., \& Pacheco, F. A. L. (2017). A multi criteria analog model for assessing the vulnerability of rural catchments to road spills of hazardous substances. Environmental Impact Assessment Review, 64, 26-36. https://doi.org/10.1016/ 